\title{
From Repression to Aggression: New Religions and Violence (Review)
}

\author{
Zuzana Kostićová
}

Zdeněk Vojtíšek's Nová náboženství a násili1 ${ }^{1}$ [New Religions and Violence] is a fresh take on a subject to which the author, the leading Czech scholar of new religions, has dedicated most of his professional life. As the author himself states in the Introduction, he has already published one wide-ranging book on the subject in 2009, Nová náboženská hnutí a kolektivní násilí [New Religious Movements and Collective Violence $].^{2}$ The older book gave a general scholarly introduction into the problem; an overview of nine movements most commonly associated with violence (Branch Davidians, Aum Shinrikyo, Heaven's Gate, etc.); and added a vast theoretical chapter which comprises more than half of the book. In this latter part, he characterized the most influential scholarly theories regarding new religions and violence and introduced his own theory. According to that, the movements run a greater risk of an explosion or implosion of violence if they fail in the process of denominalization (tied mostly to the institutionalization of charisma, softening of the movement's boundaries with the outside world, creation of a multi-generation space, etc.). In this sense, Nová náboženská hnutí a kolektivní násilí was a full-fledged academic work complete with complex terminology and presentation of the contemporary scholarly debate.

Nová náboženství a násilí follows up on this older work in many respects - but in a different way. First and foremost, the new book is intended for a wider readership, ranging from scholars and students to educated public. While the attention given to the contemporary scholarly debate is much lower, the space dedicated to individual movements is much bigger and the number of covered NRMs much greater. At the same time, the language of the book is more accessible and the structure of the monograph suggests that it was written with regard to university classes taught by the author. In other words, the book is not only a comprehensive introduction into new religions, but also a practical university textbook. While the book features full academic paraphernalia (complex footnotes and extensive bibliography), it is relatively easy to read and thus accessible for the readership which it means to address.

Another specific trait, in which the monograph differs from its predecessor, is both its rich palette of case studies and its emphasis on the Czech environment. While some attention is given to classical Western contemporary cases such as the Solar

ZdenĚK Vojtíšex, Nová náboženská hnutí a násilí [New Religions and Violence], Praha: Karolinum 2017, 285 p.

2 ZdenĚK Vojtíšš, Nová náboženská hnutí a kolektivní násilí [New Religious Movements and Collective Violence], Brno: L. Marek 2009, 460 p. 
Temple or Aum Shinrikyo, the vast majority of the cases are recruited from different historical periods (a lot of space is given to the history of the religious persecution of Anabaptists, Old Believers, and Shakers) and different geographical locations (apart from the usual American cases, the book is overflowing with mentions of China, India, Russia, Ukraine, Uganda, Iraq, and Iran). The book also lists long-established denominations with a rich history of persecution, such as Baha'i, Jehova's Witnesses, and the Latter Day Saints. The specific Czech flavor of the book is unmistakable since it is apparently specifically aimed at Czech readers, it gives a lot of space to the Immanuelites (a branch of the Grail movement to which the Author dedicated a whole separate chapter) and the Bridge to Freedom. The current character of the monograph is attested by the inclusion of the Islamic State (ISIS), which is analyzed from the perspective of New Religion Studies and interpreted as a millennial Islamic movement.

Analyzing these different movements ( 24 in total) gives the author an opportunity to explore core themes around which the book is organized - repression, conflict, martyrdom, communities, children, terrorism, charisma, revolution, aggression, and ritual violence. Every chapter is dedicated to some of them and illustrates the topic on specific religious societies and movements. While the themes are well rounded and attest for the erudition of their author, the book would certainly benefit from a more substantial theoretical conclusion, larger than the current simple, five-page epilogue. The lack of it again proves that the book is mainly intended less as a scholarly monograph and more as a popular introduction and university textbook. This only fault notwithstanding, the book is an important contribution to New Religion Studies and Czech Religious Studies in general and will undoubtedly benefit scholars, students, and members of the public alike.

\section{References}

VoJTíšEK, ZdenĚK, Nová náboženská hnutí a kolektivní násilí, Brno: L. Marek 2009, 460 p. VojtíšEK, ZDĚneK, Nová náboženství a násilí, Praha: Karolinum 2017, 285 p. 